\title{
NEONATAL HYPOGLYCEMIA: A CONTINUING DEBATE IN DEFINITION AND MANAGEMENT
}

\section{Orhideja Stomnaroska-Damcevski ${ }^{*}$, Elizabeta Petkovska ${ }^{1}$, Snezana Jancevska ${ }^{1}$, Dragan Danilovski}

\author{
${ }^{1}$ University Clinic for Gynaecology and Obstetrics, Medical Faculty, Skopje, R. Macedonia \\ ${ }^{2}$ Institute for Epidemiology and Statistics, Medical Faculty, Skopje, R. Macedonia
}

Corresponding Author: Orhideja Stomnaroska-Damcevski, Clinic for Genecology and Obstetric, Medical Faculty, Skopje, R. Macedonia; Tel: +389(0)2 705829 69; E-mail: stomnaroskao@yahoo.com

\begin{abstract}
Neonatal hypoglycemia $(\mathrm{NH})$ is one of the most common abnormalities encountered in the newborn. Maintaining glucose homeostasis is one of the important physiological events during fetal-to-neonatal transition. Transient low blood glucose concentrations are frequently encountered in the majority of healthy newborns and are the reflections of normal metabolic adaptation processes. Nevertheless, there is a great concern that prolonged or recurrent low blood glucose levels may result in long-term neurological and developmental consequences.

Strikingly, it was demonstrated that the incidence and timing of low glucose concentrations in the groups most at risk for asymptomatic neonatal hypoglycemia, did not find association between repetitive low glucose concentrations and poor neurodevelopmental outcomes. On the contrary, NH due to hyperinsulinism is strongly associated with brain injury.

Fundamental issue of great professional controversy is concerning the best manner to manage asymptomatic newborns $\mathrm{NH}$. Both, overtreating $\mathrm{NH}$ and undertreating $\mathrm{NH}$ are poles with significant potential disadvantages.

Therefore, $\mathrm{NH}$ is one of the most important issues in the day-to-day practice. This article appraises the critical questions of definition (widely accepted blood glucose concentration: $<2.6 \mathrm{mmol} / \mathrm{l}$ or $47 \mathrm{mg} / \mathrm{dl}$ ), follow-up ad management of $\mathrm{NH}$.
\end{abstract}

Keywords: Hypoglycemia, definition, management, neonates.

\section{Introduction}

Glucose is a source of energy storage in the form of glycogen, fat, and protein. Glucose provides $38 \mathrm{~mol}$ of adenosine triphosphate (ATP) per mol of glucose oxidized. Glucose is the preferred substrate for the energetic needs of the brain.

Cerebral transport of glucose is a carriermediated facilitated diffusion process that is dependent on blood glucose concentration and is not regulated by insulin. The protection against hypoglycemia is coordinated by the autonomic nervous system and by hormones, which stimulate glucose production through glycogennolysis and gluconeogenesis and limit peripheral glucose utilization.

\section{Definition}

The acute clinical signs and long term sequelae in neonates can occur within a wide range of low plasma glucose values. The greatest importance in creation of permanent damage are the duration and the severity of $\mathrm{NH}$. A specific blood glucose concentration to define $\mathrm{NH}$ for infants is a subject of great controversy [1-9]. However, it is accepted that $\mathrm{NH}$ 
is defined by a plasma glucose level of less than $30 \mathrm{mg} / \mathrm{dL}(1.65 \mathrm{mmol} / \mathrm{L})$ in the first 24 hours of life and less than $45 \mathrm{mg} / \mathrm{dL}(2.5 \mathrm{mmol} / \mathrm{L})$ thereafter.

It is of note that having in view the potential catastrophic sequelae many authors take the values of blood glucose $<50 \mathrm{mg} / \mathrm{dL}$ in neonates as a threshold that must be treated [10]. In other age groups HG has other values as criterion: in infants a blood glucose value of less than $40 \mathrm{mg} / \mathrm{dL}(2.2 \mathrm{mmol} / \mathrm{L})$, in children $<50$ $\mathrm{mg} / \mathrm{dL}$.

The normal fasting blood glucose values are between $80-90 \mathrm{mg} / \mathrm{dL}$ (4.4-5 mmol/L). There is a transient postprandial increase to $120-140 \mathrm{mg} / \mathrm{dL}(6.6-7.7 \mathrm{mmol} / \mathrm{L})$ and a rapid return to the preprandial level within 2 hours. It is of note that in neonates the serum glucose levels are declining in the first 1-3 hours of life and then spontaneously increase.

Hypoxemia and ischemia in neonates may increase the harmful effects of hypoglycemia on brain damage. It is of note that, the lower limit of blood glucose normality in newborns with hypoxemia and ischemia has not been determined.

\section{Frequency}

HG is the most common metabolic problem in neonates. The estimated frequency is dependent on the definition used, the population investigated, the method and timing of feeding (early versus later feeding), the type of glucose assay [11], the compartment measured (serum concentrations are higher than concentrations in the whole blood).

In USA, the incidence of symptomatic hypoglycemia in newborns is estimated to 1.33 per 1000 live births [10]. In Japan, in newborns born at 35-36 weeks gestation more than $80 \%$ of the admissions to the neonatal intensive care unit after birth were due to apnea or HG [12]. In a New Zealand PICU unit 50\% of the babies had NH [13].

\section{Consequences}

Sustained, repetitive hypoglycemia and very low glucose levels in neonates may cause neurologic damage, mental retardation, epilepsy, and personality disorders [10, 14]. Even early transient $\mathrm{NH}$ resulted in lower achievement of fourth-grade literacy and mathematics achievement tests at age 10 years [15].

Severe hypoglycemia may also impair cardiovascular function. HG in VLBW infants is associated with higher neonatal mortality [16, 17]. Both the duration of hospital stay and neonatal mortality were increased in $\mathrm{NH}$ or hyperglycemia $[18,19]$. Permanent brain damage is found in $25-50 \%$ of patients with severe recurrent symptomatic hypoglycemia younger than 6 mo of age [10]. In addition, it was reported that hypoxemia and ischemia may potentiate the permanent brain damage caused by hypoglycemia [10].

The pathologic changes consequent to $\mathrm{HG}$ are atrophic gyri, reduced myelination in cerebral white matter, and atrophy in the cerebral cortex. There are no brain infarcts characteristics of the hypoxia-ischemia processes [10].

\section{Etiology}

Hyperinsulinism, or persistent hyperinsulinemic hypoglycemia of infancy (PHHI), is the most common cause of hypoglycemia in the first 3 months of life. PHHI is very frequent in infants of mothers with diabetes.

Limited glycogen stores (prematurity, intrauterine growth retardation), increased glucose use (hyperthermia, polycythemia, sepsis, growth hormone deficiency), decreased glycolgenolysis, gluconeogenesis, or use of alternate fuels (inborn errors of metabolism, adrenal insufficiency) and depleted glycogen stores (asphyxia-perinatal stress, starvation) also cause neonatal hypoglycaemia.

Some rare inborn errors of metabolism lead to neonatal hypoglycemia (20): carbohydrate metabolism disorders $(>1: 10,000)$, fatty acid oxidation disorders $(1: 10,000)$, hereditary fructose intolerance $(1: 20,000$ to $1: 50,000)$, glycogen storage diseases $(1: 25,000)$, galactosemia $(1: 40,000)$, organic acidemias $(1: 50,000)$, phosphoenolpyruvate carboxykinase deficiency, primary lactic acidosis.

HG in infants, children, and teenagers can be caused by poisonings/drugs (ethanol, isoniazid, insulin, propranolol, quinine, disopyramide, salicylates, oral hypoglycemics, pentamidine, Vacor [rat poison]), liver disease (hepatoma, Reye syndrome, hepatitis, cirrhosis), 
amino acid and organic acid disorders (glutaric aciduria, propionic acidemia, methylmalonic acidemia, 3-hydroxy-3-methylglutaric aciduria, maple syrup urine disease, tyrosinosis) and systemic disease (cardiogenic shock, respiratory distress syndrome, sepsis, burns). BeckwithWiedemann syndrome can also have severe HG [21].

\section{Pathophysiology}

The factors that predispose or cause $\mathrm{NH}$ include changes in hormone secretion, changes in hormone receptors, changes in enzymatic activities. In addition, in newborns there are inadequate reserve of hepatic glycogen, inadequate muscle stores as a source of amino acids for gluconeogenesis, inadequate lipid stores for the release of fatty acids. Fetal glucose is derived entirely from the mother through placental transfer.

After delivery, there is a three- to fivefold increase in glucagon concentration within minutes to hours, the fall of insulin concentrations for several days, a strong surge in catecholamine secretion and elevated growth hormone levels as a response to the surge of catheholamines. The net effect is the mobilization of glucose via glycogenolysis and gluconeogenesis, activation of lipolysis, and promotion of ketogenesis. As consequence, liver glycogen stores are rapidly depleted within hours, gluconeogenesis from alanine is intensified to $\sim 10 \%$ of glucose turnover. It is of note that the increase in the FFA and ketones spares the utilization of glucose.

\section{High risk neonates}

Newborns who have a high-risk of hypoglycemia and need of hypoglycemia screening in the first hour of life [22] are newborns who weigh more than $4 \mathrm{~kg}$ or less than $2 \mathrm{~kg}$, large for gestational age (LGA) infants who are above the 90th percentile, small for gestational age (SGA), infants below the 10th percentile [23], and infants with intrauterine growth restriction [24-31]. In addition, high risk newborns are children with gestational age less than 37 weeks, children with sepsis [32] or born to a mother having chorioamnionitis or toxemia. The prevalence of $\mathrm{NH}$ in neonates born 34 weeks vs 35 to 36 weeks vs term was $26 \%$ vs $16 \%$ vs $1 \%$ [33].

High risk newborns are also children born to insulin-dependent mothers (1: 1000 pregnant women) or mothers with gestational diabetes ( $2 \%$ of pregnant women) $[34,35]$.

\section{Hyperinsulinemia}

Hyperinsulinism is the most common cause of persistent hypoglycemia in early infancy. It is frequent in macrosomic newborns. The lesser degree of hyperinsulinaemia results in $\mathrm{HG}$ after the first few weeks to months.

The characteristics are the rapid development of fasting hypoglycemia within 4-8 hr of food deprivation, the absence of ketonemia or acidosis, the need for high rates of exogenous glucose, and elevated C-peptide or proinsulin levels.

Plasma insulin concentrations in $\mathrm{HG}$ are $>$ 5-10 $\mu \mathrm{U} / \mathrm{mL}$. Some authors ask for more stringent criteria of insulin $>2 \mu \mathrm{U} / \mathrm{mL}$ with hypoglycemia.

The insulin $(\mu \mathrm{U} / \mathrm{mL})$ : glucose $(\mathrm{mg} / \mathrm{dL})$ ratio is commonly $>0.4$, and plasma insulin-like growth factor binding protein-1 (IGFBP-1), ketones, and FFA levels are low. The critical sample has to be obtained: glucose, insulin, ketones, and FFAs in the same sample at the time of clinically manifested hypoglycemia. Provocative tests with tolbutamide or leucine are usually not necessary in infants. On the other hand the rapid response to glucagon administration implies that the glucose mobilization has been restrained by insulin and that glycogenolytic are intact.

Hyperinsulinaemia can be caused by diffuse $\beta$-cell hyperplasia or focal $\beta$-cell microadenoma, treated with pancreatectomy and curative resection respectively.

Persistent hyperinsulinemic hypoglycemia of infancy (PHHI) is a genetic disorder caused by mutations in the regulation of the potassium channel which is closely involved in insulin secretion by the pancreatic $\beta$ cell [10].

The ATP-sensitive potassium channel in the cell membrane ( $\mathrm{K}_{\text {ATP }}$ channel) has two subunits: the $K_{I R} 6.2$ channel, and a regulatory component known as the sulfonylurea receptor (SUR). 
Inactivating mutations prevent the potassium channel from opening allowing constant inward flux of calcium and continuous insulin secretion.

The genes for glucokinase and glutamate dehydrogenase can also have inactivating mutations which also close the potassium channel and result in hyperinsulinism. A gain of function mutation of glutamate dehydrogenase causes PHHI with mild hyperamoniaemia. In fact there are three forms of the familial PHHI: autosomal recessive forms, autosomal dominant form and form with a mild hypearmoniaemia [10].

The treatment with diazoxide in the autosomal recessive PHHI fails to control hypoglycemia, somatostatin is partially effective and pancreatectomy is usually indicated.

The distinction between focal and diffuse cases of persistent hyperinsulinism is complex. CT and MRI are of little help, transhepatic portal vein catheterization; selective pancreatic venous samplings to measure insulin are needed to localize a focal lesion. In addition, there is a selective catheterization of the arterial branches supplying the pancreas, followed by infusion of a secretagogue such as calcium and a portal vein sampling for insulin concentration. $18 \mathrm{~F}$ labeled L-dopa combined with PET scanning can be helpful. The most precise diagnosis is the intraoperative histological characterization.

\section{Clinical presentation}

There are two parts of newborn symptoms of HG: the decreased availability of glucose for the brain and the adrenergic stimulation. The clinical signs vary from asymptomatic HG to severe central nervous system (CNS) and cardiopulmonary disturbances. Alterations in the levels of consciousness, unresponsiveness, lethargy, hypotonia, poor feeding, jitteriness, tremulousness, irritability, stupor, seizures, vomiting - all are part of the neonatal HG. In addition, congestive heart failure, cyanosis, apnea, a high-pitched cry and hypothermia may be present. It is of note that the autonomic nervous system manifestations include pallor, diaphoresis, tachycardia, hunger, anxiety, nausea, and vomiting.

As many neonates have additional metabolic or clinical conditions (hypoxia-ischemia, infections...) the signs of $\mathrm{HG}$ are becoming even more variable. It has to be stressed that hypoxia, perinatal distress, 5-minute Apgar scores of less than 5 are to be considered as causes of $\mathrm{HG}$.

In contrast to the neonates, older children manifest mental confusion, behavioral changes, headache, amnesia, decreased visual acuity, diplopia, dysarthria, aphasia, ataxia, difficulty concentrating, somnolence, seizures, hemiplegia, paresthesias, dizziness, and coma.

The profound or long lasting HG signs and are not easily or rapidly reversed with glucose replacement treatment.

\section{High Risk Newborns}

There is a long list of high risk newborns. High risk newborns are children with gestational age less than 37 weeks, newborns who weigh more than $4 \mathrm{~kg}$ or less than $2 \mathrm{~kg}$, large for gestational age (LGA) infants, small for gestational age (SGA) [23], and infants with intrauterine growth restriction. In addition high risk neonates are newborns with sepsis or born to a mother having chorioamnionitis, toxemic mothers, children born to insulin-dependent diabetic mothers or mothers with gestational diabetes.

The assessment of the high risk newborns can be facilitated with the use of specially designed scores. CRIB (clinical risk index for babies) [37] and SNAPPE (score for neonatal acute physiology-perinatal extension) [38], e.g. the newer revisions SNAPPE-II [39] are proven to be of assistance in determining the neonatal risk. The scores calculate the risk by considering several specifics: BW, SGA, Apgar at five minutes, lowest $\mathrm{pH}$, urine output, lowest mean blood pressure, lowest temperature, worst $\mathrm{PaO}_{2} / \mathrm{Fio}_{2}$ ratio, occurrence of seizures. The CRIB-II [40] is easier to use for the hospital praxis as it uses five parameters: sex, BW, GA, worst base excess, temperature at admission.

\section{Differential Diagnoses}

The list of causes of neonatal HG is particularly long. Endocrine causes include growth hormone deficiency, adrenal insufficiency and hypothyroidism. Munchausen syndrome and Reye syndrome should also be considered.

Hepatomegaly can suggest glycogenstorage disease, Beckwith-Wiedemann syndro- 
me should be considered if gigantism, macroglossia or hemihypertrophy are observed [21]. The mothers' history of treatment with terbutaline, oral hypoglycemic agents or beta blockers indicates a need for close monitoring of the child.

\section{Diagnosis}

In the diagnosis of neonatal $\mathrm{HG}$ one should take into account that the whole blood measurements of glucose underestimate the plasma glucose concentration by $10-15 \%$. On the contrary, arterial and capillary samples overestimate the plasma glucose concentration by $10 \%$. In the diagnosis of hypoerinsulinemic $\mathrm{HG}$ it is of note that normally plasma insulin concentration are between $5-10 \mu \mathrm{U} / \mathrm{mL}$, when glucose is less than $40 \mathrm{mg} / \mathrm{dL}$. It is important to get the first voided urine dipstick for ketones, as no ketones in $\mathrm{HG}$ means that fat is not metabolized from adipose tissue which indicates hyperinsulinism or that fat cannot be used for ketone body formation which indicates enzymatic defects in fatty acid oxidation.

Aminoacidemias, organic acidurias, urea cycle disorders and fatty acid oxidation disorders [41] should be sought for as causes of neonatal HG. It is of note that an extra tube of serum or plasma should be kept for eventual additional analysis.

Sampling intervals are of particular importance: initially every hour, until the glucose concentrations are stabilized, than every $4 \mathrm{~h}$ (the maximum sampling interval) $[6,42]$. The sampling must be adjusted to the clinical presentation of the $\mathrm{HG}$, and sampling every 30 minutes is sometimes necessary.

\section{Treatment}

In neonates glucose concentrations decrease in the first hour or two after birth, reach a nadir after about two hours, and then start to increase to stable concentrations. As precise timing and intervals for glucose concentration measurements have not been firmly established, high risk newborns need to be monitored early and frequently, until they maintain normal before-feeding glucose concentrations through several fast-feed cycles [6]. In addition, there is a long standing debate about the specific concentration of plasma glucose associated with cerebral injury. The debate resulted in no specific glucose concentration found as a cause for permanent cerebral injury. Therefore, the most important clinical approach is the early identification of newborns at risk. For all newborns, early feeding with breast milk or formula is of great importance. Asymptomatic hypoglycemia requires no treatment but feeding and observation [43]. In neonates with proven HG the goal is to promptly reverse, normalize and maintain the desired glucose concentrations [44]. Most authors recommend the goal to maintain a blood glucose level of at least 45 $\mathrm{mg} / \mathrm{dL}(2.5 \mathrm{mmol} / \mathrm{L})$ [10] in order to prevent brain damage. It is of note that the symptomatic HG is to be treated by the "minibolus" approach: $200 \mathrm{mg} / \mathrm{kg}$ or $2 \mathrm{~mL}$ of D10W $(10 \%$ dextrose in water) IV over 5 minutes. The minibolus is than followed by a constant infusion of dextrose at $6-8 \mathrm{mg} / \mathrm{min} / \mathrm{kg}$ [45]. Alternatively, a constant infusion of at least 6-8 $\mathrm{mg} / \mathrm{min} / \mathrm{kg}$ glucose has been proven to normalize glucose concentrations 5-10 minutes later than those produced by the minibolus. The treatment might take 2-4 weeks. Recurrent hypoglycemia has the goal to achieve blood glucose concentrations $>2.0$ but $<4.5 \mathrm{mmol} / \mathrm{L}$ ( $>45$ but $<80 \mathrm{mg} / \mathrm{dL}$ ). Two further considerations are: hyperglycemia is to be avoided - it causes rapid insulin release and rebound hypoglycaemia and, rapid IV boluses of hypertonic dextrose can cause osmotic injuries.

In newborns all other supportive measures have to be applied: an intravenous (IV) line, monitoring oxygen, anticonvulsants, and treatment of acidosis $(\mathrm{pH}<7.1)$.

Persistent hypoglycemia is always requiring additional investigations. There are two conditions that should be recognized and treated: fatty acid oxidation disorders and hyperinsulinism. Those conditions are often refractory to glucose replacement [46].

Diazoxide, analogs of somatostatine, glucagon are used to treat persistent HG. Diazoxide is an inhibitor of pancreatic insulin release. The drug is effective and is effective in PHHI, SGA children and in neonates with maternal toxemia or perinatal asphyxia. The somatostatin analog (octreotide) suppresses insulin secretion. Cortisol is not used to treat neonatal $\mathrm{HG}$, as it has a minimal acute benefit. 


\section{REFERENCES}

1. Bonacruz GL, Arnold JD, Leslie GI, Wyndham L, Koumantakis G. Survey of the definition and screening of neonatal hypoglycaemia in Australia. J Paediatr Child Health. 1996; 32(4): 299-301.

2. Cornblath M, Hawdon JM, Williams AF, AynsleyGreen A, Ward-Platt MP, Schwartz R, Kalhan SC. Controversies regarding definition of neonatal hypoglycemia: suggested operational thresholds. Pediatrics. 2000; 105(5): 1141-1145.

3. Deshpande S, Ward Platt M. The investigation and management of neonatal hypoglycaemia. Semin Fetal Neonatal Med. 2005; 10(4): 351-61.

4. Laptook A, Jackson GL. Cold stress and hypoglycemia in the late preterm ("near-term") infant: impact on nursery of admission. Semin Perinatol. 2006; 30(1): 24-27.

5. Rozance PJ, Hay WW., Jr. Hypoglycemia in newborn infants: features associated with adverse outcomes. Biology of the Neonate. 2006; 90: 74-86.

6. Alkalay AL, Sarnat HB, Flores-Sarnat L, Elashoff JD, Farber SJ, Simmons CF. Population meta-analysis of low plasma glucose thresholds in full-term normal newborns. Am J Perinatol. 2006; 23(2): 115119.

7. Rozance PJ, Hay, WW Jr. Describing hypoglycemia - definition or operational threshold? Early Hum Dev. 2010; 86(5): 275-280.

8. Faustino EV, Hirshberg EL, Bogue CW. Hypoglycemia in critically ill children. J Diabetes Sci Technol. 2012; 6(1): 48-57.

9. Tin W. Defining neonatal hypoglycaemia: a continuing debate. Semin Fetal Neonatal Med. 2014; 19(1): 27-32.

10. Sperling M. Hypoglycaemia. In: Nelson Textbook of Pediatrics, Saunders, Philadelphia, 2007; 655669.

11. Balion C, Grey V, Ismaila A, Blatz S, Seidlitz W. Screening for hypoglycemia at the bedside in the neonatal intensive care unit (NICU) with the Abbott PCx glucose meter. BMC Pediatr. 2006; 6: 28.

12. Ishiguro A, Namai Y, Ito YM. Managing "healthy" late preterm infants. Pediatr Int. 2009; 51(5): 720725.

13. Harris DL, Weston PJ, Harding JE. Incidence of neonatal hypoglycemia in babies identified as at risk. J Pediatr. 2012; 161(5): 787-791.

14. Menni F, de Lonlay P, Sevin C, et al. Neurologic outcomes of 90 neonates and infants with persistent hyperinsulinemic hypoglycemia. Pediatrics. 2001; 107: 476-479.

15. Kaiser JR, Bai S, Gibson N, Holland G, Lin TM, Swearingen CJ, et al. Association between Transient Newborn Hypoglycemia and Fourth-Grade Achievement Test Proficiency: A Population-Based Study. JAMA Pediatr. 2015 Aug 24. doi: 10.1001/jamapediatrics.2015.1631. [Epub ahead of print]
16. Shankaran S, Fanaroff AA, Wright LL, Stevenson DK, Donovan EF, Ehrenkranz RA, et al. Risk factors for early death among extremely low-birthweight infants. Am J Obstet Gynecol. 2002; 186(4): 796-802.

17. Fendler W, Walenciak J, Mlynarski W, Piotrowski A. Higher glycemic variability in very low birth weight newborns is associated with greater early neonatal mortality. J Matern Fetal Neonatal Med. 2012; 25(7): 1122-1126.

18. Srinivasan V, Spinella PC, Drott HR, Roth CL, Helfaer MA, Nadkarni V. Association of timing, duration, and intensity of hyperglycemia with intensive care unit mortality in critically ill children. Pediatr Crit Care Med. 2004; 5(4): 329-336.

19. Wintergerst KA, Buckingham B, Gandrud L, Wong BJ, Kache S, Wilson DM. Association of hypoglycemia, hyperglycemia, and glucose variability with morbidity and death in the pediatric intensive care unit. Pediatrics. 2006; 118(1): 173-179.

20. Raghuveer TS, Garg U, Graf WD. Inborn errors of metabolism in infancy and early childhood: an update. Am Fam Physician. 2006; 73(11): 1981-90.

21. Ramadan GI, Kennea NL. Beckwith-Wiedemann syndrome associated with congenital hypothyroiddism in a preterm neonate: a case report and literature review. J Perinatol. 2009; 29(6): 455-457.

22. Newborn Nursery QI Committee. Portland (ME): The Barbara Bush Children's Hospital at Maine Medical Center; 2004. Neonatal hypoglycemia: initial and follow up management. National Guideline Clearinghouse.

23. Narchi H, Skinner A, Williams B. Small for gestational age neonates--are we missing some by only using standard population growth standards and does it matter? J Matern Fetal Neonatal Med. 2010; 23(1): 48-54.

24. Chia YT, Chua S, Thai AC, Yeoh SC, Kek LP, Selamat N, Ratnam SS. Obstetric outcome of pregestational diabetic pregnancies. Singapore Med J. 1995; 36(5): 498-500.

25. Zanardo V, Cagdas S, Golin R, Trevisanuto D, Marzari F, Rizzo L. Risk factors of hypoglycemia in premature infants. Fetal Diagn Ther. 1999; 14(2): 63-67.

26. Kilic M, Aygun C, Kaynar-Tuncel E, Kucukoduk S. Does birth weight discordance in preterm twins affect neonatal outcome? J Perinatol. 2006; 26(5): 268-272.

27. Mericq V. Prematurity and insulin sensitivity. Horm Res. 2006; 65(Suppl 3): 131-136.

28. Meier PP, Furman LM, Degenhardt M. Increased lactation risk for late preterm infants and mothers: evidence and management strategies to protect breastfeeding. J Midwifery Womens Health. 2007; 52(6): 579-587.

29. Melamed N, Klinger G, Tenenbaum-Gavish K, Herscovici T, Linder N, Hod M, Yogev Y. Short-term neonatal outcome in low-risk, spontaneous, single- 
ton, late preterm deliveries. Obstet Gynecol. 2009; 114(2 Pt 1): 253-260.

30. Kalyoncu O, Aygun C, Cetinoglu E, Kucukoduk S. Neonatal morbidity and mortality of late-preterm babies. J Matern Fetal Neonatal Med. 2010; 23(7): 607-612.

31. Mitanchez D. Management of infants born to mothers with gestational diabetes. Paediatric environment. Diabetes Metab. 2010; 36(6 Pt 2): 587-594.

32. Wolfe RR. Sepsis as a modulator of adaptation to low and high carbohydrate and low and high fat intakes. Eur J Clin Nutr. 1999; 53: S136-S142.

33. Visruthan NK, Agarwal P, Sriram B, Rajadurai VS. Neonatal Outcome of the Late Preterm Infant (34 to 36 Weeks): The Singapore Story. Ann Acad Med Singapore. 2015; 44(7): 235-43.

34. Carrapato MR, Marcelino F. The infant of the diabetic mother: The critical developmental windows. Early Pregnancy. 2001; 5(1): 57-58.

35. Alam M, Raza SJ, Sherali AR, Akhtar AS. Neonatal complications in infants born to diabetic mothers. J Coll Physicians Surg Pak. 2006; 16(3): 212-215.

36. Rozance PJ. Update on neonatal hypoglycemia. Curr Opin Endocrinol Diabetes Obes. 2014; 21(1): 45-50.

37. The International Neonatal Network. The CRIB (Clinical Risk Index for Babies) score: a tool for assessing initial neonatal risk and comparing performance of neonatal intensive care units. Lancet 1993; 342: 193-8.

38. Richardson DK, Phibbs CS, Gray JE, et al. Birth weight and illness severity: independent predictors of neonatal mortality. Pediatrics 1993; 91: 969-75.

39. Richardson DK, Corcoran JD, Escobar GJ, et al. SNAP-II and SNAPPE-II: simplified newborn illness severity and mortality risk scores. J Pediatr2001; 138: 92-100.

40. Parry G, Tucker J, Tarnow-Mordi WO. CRIB-II: an update of the clinical risk index for babies score. Lancet 2003; 361: 1789-91.

41. Rinaldo P, Matern D, Bennett MJ. Fatty acid oxidation disorders. Annu Rev Physiol. 2002; 64: 477-502.

42. Van Herpe T, Vanhonsebrouck K, Mesotten D, De Moor B, Van den Berghe G Glycemic control in the pediatric intensive care unit of Leuven: two years of experience. J Diabetes Sci Technol. 2012; 6(1): 15-21.

43. American Academy of Pediatrics Committee on Fetus and Newborn. Pediatrics. 1993; 92: 474-476.

44. Canadian Pediatric Society. Screening guidelines for newborns at risk for low blood glucose. Paediatr Child Health. 2004; 9(10): 3-10.

45. Lilien LD, Pildes RS, Srinivasan G, Voora S, Yeh TF. Treatment of neonatal hypoglycemia with minibolus and intraveous glucose infusion. J Pediatr. 1980; 97: 295-298.
46. Rozance PJ, Hay WW. Jr Hypoglycemia in newborn infants: features associated with adverse outcomes. Biology of the Neonate. 2006; 90: 74-86.

Резиме

\section{НЕОНАТАЛНА ХИПОГЛИКЕМИЈА (НХ): КОНТИНУИРАНА ДЕБАТА ЗА НЕЈЗИНО ДЕФИНИРАЊЕ И ЛЕКУВАЊЕ}

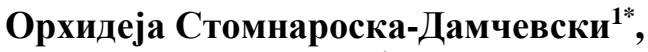 Елизабета Петковска ${ }^{1}$, Снежана Јанчевска ${ }^{1}$, Драган Даниловски ${ }^{2}$}

${ }^{1}$ Клиника за гинекологија и акушерство, Медицински факултет, Скопје, Р. Македонија

${ }^{2}$ Институт за епидемиологија и статистика, Медицински факултет, Скопје, Р. Македонија

HX е една од најчестите биохемиски аномалии кај новороденото дете. Одржување на хомеостазата на шеќерот е една од најважните физиолошки ситуации во транзицијата од фетален во неонатален период. Транзиторна хипогликемија често се среќава кај здрави новородени како знак на адаптивен процес. Треба да се нагласи дека пролонгирана и/или повторувачка ХГ може да резултира во трајни невролошки и развојни оштетувања. Интересно е дека некои студии не најдоа поврзаност помеѓу времето на настанување и нивото на ХГ кај новородените со ризик и подоцнежни невроразвојни нарушувања. Од друга страна, ХГ поради хиперинсулинизам е поврзана со оштетувања на мозокот.

Како најдобро да се менаџира ХГ кај асимптоматски новородени е фундаментално прашање за кое постои голема стручна котроверзија. И премногу и премалку третирање имаат неповолни странични ефекти. Затоа ХГ е еден од најважните катадневни проблеми во секојдневната неонатолошка практика. Овој труд ги дискутира критичните прашања на дефиниција на хипогликемија (широко прифатена $<2.6$ ммол/л или 47 мг/дл), следење и лекување на НХ.

Клучни зборови: хипогликемија, дефиниција, лекување, новородени 